\title{
Vascularization in Tissue Engineering: Angiogenesis versus Inosculation
}

\author{
M.W. Laschke M.D. Menger \\ Institute for Clinical and Experimental Surgery, University of Saarland, Homburg/Saar, Germany
}

\author{
Key Words \\ Angiogenesis · Inosculation · Scaffold · Tissue engineering • \\ Vascularization
}

\begin{abstract}
Background/Purpose: The key challenge in tissue engineering is the establishment of an efficient vascularization for tissue constructs guaranteeing long-term survival and function. Vascularization may be achieved by the stimulation of angiogenesis or the inosculation of preformed microvascular networks within the implants to the host microvasculature. The present review provides an overview of these two concepts applied in tissue engineering. Methods: A literature search was performed in PubMed for publications focusing on vascularization, angiogenesis and inosculation in tissue engineering. Results: Several strategies have been proposed to stimulate the ingrowth of new blood vessels into tissue constructs. These include the modification of the chemical composition and architecture of scaffolds, their bioactivation by incorporation of growth factor delivery systems or by cell seeding as well as the stimulation of stem cell recruitment. However, because angiogenesis is a time-consuming process, all of these approaches cannot prevent ischemic cell death within larger 3-dimensional tissue constructs during the initial phase after implantation. To overcome this problem, in vitro or in situ prevascularization has emerged as a novel concept in tissue engineering. This bears the advantage that preformed microvascular networks within tis-
\end{abstract}

sue constructs simply have to inosculate with the host microvasculature at the implantation site to get completely bloodperfused within a short period of time. Conclusions: During the last years, considerable progress has been made in the development of promising vascularization strategies in tissue engineering. Particularly the inosculation of preformed microvascular networks has the great potential to markedly improve the survival of tissue constructs after implantation. The optimization of this vascularization strategy may pave the way for a broad clinical use of tissue engineering applications in the future.

Copyright $\odot 2012$ S. Karger AG, Basel

\section{Introduction}

Tissue engineering is a rapidly growing field of research, which is driven by the urgent need for tissue substitutes and transplantable organs in daily clinical practice. In fact, the generation of functional tissue constructs by combining the principles of engineering and life sciences may dramatically change human health care in the future, offering the exciting possibility to restore, maintain or improve tissue function at any time independently from available donor organs [1].

The classical tissue engineering approach involves the isolation and seeding of organospecific cells or multipotent stem cells on different scaffold biomaterials. The scaffolds serve as artificial extracellular matrices for the

\section{KARGER \\ Fax +4161306 1234 \\ E-Mail karger@karger.ch}

www.karger.com
(C) 2012 S. Karger AG, Basel

0014-312X/12/0482-0085\$38.00/0

Accessible online at:

www.karger.com/esr
Matthias W. Laschke, MD, PhD

Institute for Clinical and Experimental Surgery

University of Saarland

DE-66421 Homburg/Saar (Germany)

Tel. +496841 162 6554, E-Mail matthias.laschke@uks.eu 


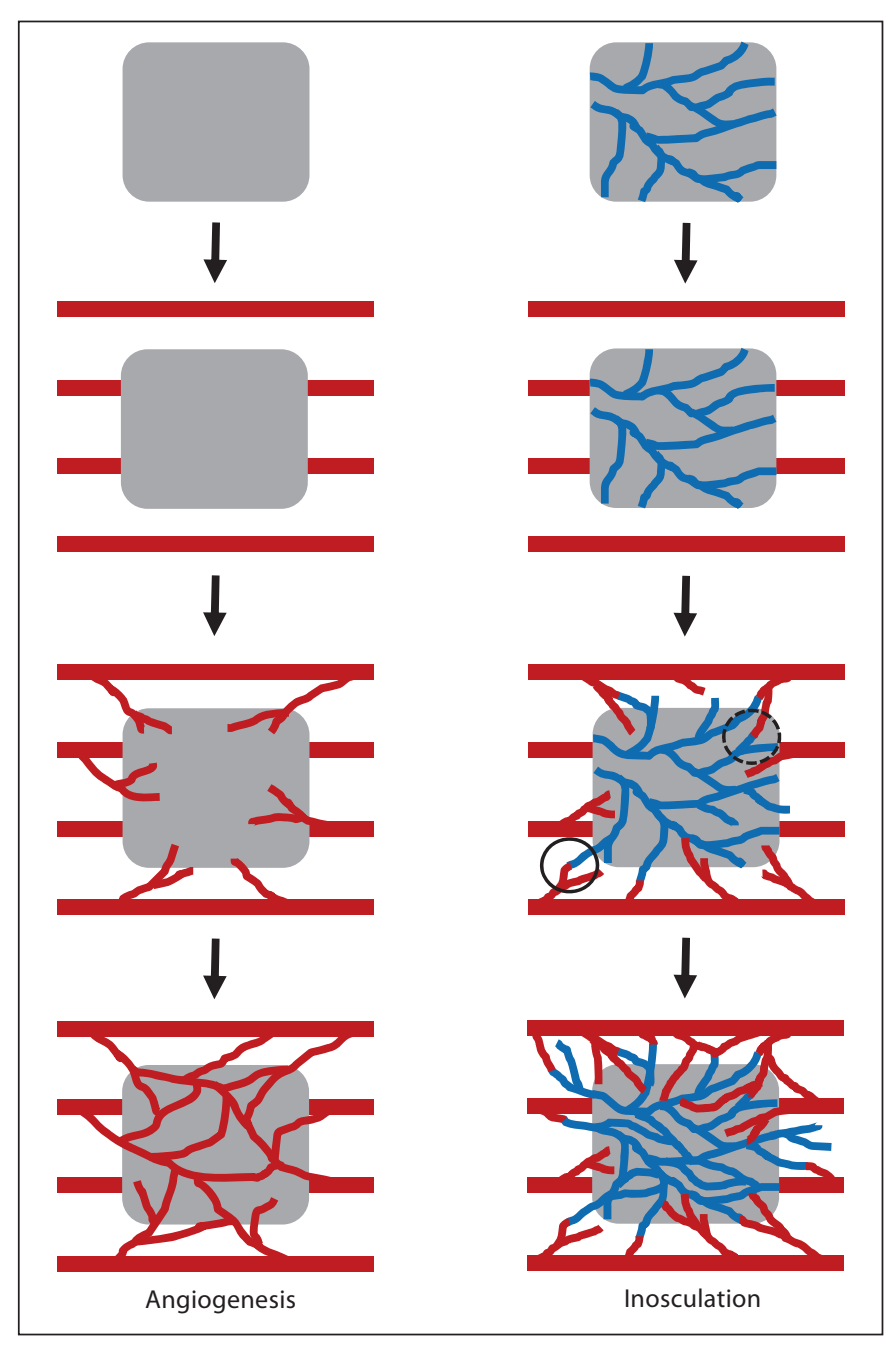

Fig. 1. Schematic drawing of the two principal vascularization strategies in tissue engineering, i.e. angiogenesis and inosculation. The angiogenesis approach is characterized by the ingrowth of vascular sprouts from the host microvasculature (red vessels) into an implanted tissue construct, which finally form a new microvascular network. In case of the inosculation approach, a preformed microvascular network (blue vessels) is generated within a tissue construct prior to its implantation. This bears the advantage that the preformed microvessels simply have to develop interconnections (inosculation) to the host microvasculature to get fully blood-perfused within a short period of time. These interconnections may develop within the construct (internal inosculation, encircled by dashed line) or within the surrounding host tissue (external inosculation, encircled by closed line).

cells to attach, to proliferate and finally to form tissue constructs for implantation into a defect site $[2,3]$. A major prerequisite for the long-term survival and function of these constructs is their sufficient vascularization after implantation. In particular, the cells in the center of large 3-dimensional tissue constructs are crucially dependent on a vascular supply of their own, because their oxygen and nutrient demand cannot be covered only by diffusion processes from the host tissue [4]. Accordingly, the development of efficient vascularization strategies for engineered tissue constructs is a key challenge [5], which has to be mastered in order to pave the way for a broad clinical use of tissue engineering applications.

During the last few years, two principal vascularization strategies have emerged in the field of tissue engineering (fig. 1). The first strategy focuses on the ingrowth of newly formed blood vessels into implanted tissue constructs from the surrounding host tissue by stimulating angiogenesis [6]. On the other hand, a rapid blood supply of tissue constructs may be achieved by inosculation [7]. In this case, preformed microvascular networks are generated within tissue constructs prior to their implantation. At the implantation site, these networks simply have to develop interconnections with the host microvasculature to get fully reperfused within a short period of time.

The present review gives an overview of studies focusing on angiogenesis and inosculation in tissue engineering. Moreover, it highlights the most interesting approaches, which may be used for the optimization of these processes with the central aim to achieve a rapid and sufficient vascularization of tissue constructs.

\section{Angiogenesis in Tissue Engineering}

The ingrowth of newly formed blood vessels into an implanted tissue construct is a highly dynamic process. The first step in this process is the activation of the host microvasculature at the implantation site by angiogenic growth factors, such as vascular endothelial growth factor (VEGF) or basic fibroblast growth factor [8]. These factors may originate from different sources. They may be produced by cells of the host tissue itself due to tissue injury during the implantation procedure or in consequence of an inflammatory response to the implant [7]. On the other hand, it is possible to generate tissue constructs with artificial protein delivery systems or different cell types, which are capable of releasing angiogenic growth factors [9-11].

Upon angiogenic activation, the endothelial cells of the host microvasculature start to produce matrix metalloproteinases, resulting in the degradation of their basement membrane [12]. This is the prerequisite for their subsequent migration into the surrounding interstitium, 
which is morphologically reflected by the formation of vascular buds and sprouts. The sprouts progressively grow into the implanted tissue construct and interconnect with each other to develop new blood-perfused microvascular networks [13]. The wall of these networks is finally stabilized by the production of extracellular matrix compounds and the recruitment of smooth muscle cells or pericytes [14].

Accordingly, successful vascularization of a tissue construct via angiogenesis is dependent on the coordinated sequence of various humoral and cellular mechanisms and, in particular, the close interaction between the host tissue and the implant. This multistep process of angiogenic vascularization offers different possibilities to stimulate and accelerate the formation of vascular networks in tissue constructs.

\section{Stimulating Angiogenesis in Tissue Constructs}

Several approaches, which may improve vascular ingrowth into implanted tissue constructs, are currently under investigation. These include (i) the modification of the chemical composition and architecture of scaffolds, (ii) their bioactivation by incorporation of growth factor delivery systems or by cell seeding and (iii) the stimulation of stem cell recruitment at the implantation site.

During the last few years, different studies have shown that the vascularization of a scaffold is crucially dependent on its chemical composition $[13,15,16]$. Of interest, there is a close relation between the inflammatory and the angiogenic host tissue response to an implanted scaffold biomaterial. For instance, Rücker et al. [13] found that poly-L-lactide coglycolide (PLGA) scaffolds induce slight inflammation after implantation into the dorsal skin fold chamber of Balb/c mice. This is associated with a marked angiogenic host tissue response and a good vascularization of the implants after 14 days. In contrast, collagen-chitosan-hydroxyapatite hydrogel scaffolds of identical architecture induce severe inflammation, resulting in a complete lack of ingrowth of newly formed microvessels into the implants. Additional studies have shown that polyurethane scaffolds, which exhibit an excellent in vivo biocompatibility, are characterized by a poor vascularization $[17,18]$. These findings indicate that scaffold biomaterials with slight proinflammatory properties may be appropriate for the stimulation of the angiogenic process at the implantation site.

Besides the chemical composition, the architecture of scaffolds is a further important determinant for adequate vascularization. Druecke et al. [19] systematically analyzed the effect of pore size on the vascularization of poly(ether ester) block copolymer scaffolds. Of interest, they demonstrated that blood vessel ingrowth was markedly improved in scaffolds with large pores of 250-300 $\mu \mathrm{m}$ when compared to implants with smaller pore sizes. During the last few years, sophisticated techniques have been established for the fabrication of scaffolds exhibiting a highly interconnected porous structure with controllable pore sizes [19-21]. By now, it is even possible to generate scaffolds with distinct porosity levels. For instance, Yang et al. [22] applied a rapid prototyping technique for the fabrication of ceramic scaffolds with submicrometer pores to improve cell/surface interactions, pores of tens of micrometers to support the ingrowth of bone tissue and corridors of $100-600 \mu \mathrm{m}$ to enable vascularization. The use of novel microfabrication techniques further offers the exciting possibility to induce directional blood vessel ingrowth into polymer scaffolds along preformed network structures with a vascular geometry $[4,23]$.

A common strategy to improve scaffold vascularization is the stimulation of the angiogenic host tissue response at the implantation site by incorporation of angiogenic growth factors into the implants. For this purpose, VEGF [24, 25], basic fibroblast growth factor [26, 27], platelet-derived growth factor [28] and angiogenin [29] are the most frequently used factors. They can be covalently immobilized $[30,31]$ or loaded on the scaffold surface via collagen coating [32]. Moreover, it is possible to fill porous scaffolds with growth factor-containing gels [10]. Alternatively, the factors may be bound to nanoparticles [33] or encapsulated into microspheres with defined degradation rates [34-38]. This enables the fabrication of implants containing several growth factor delivery systems with controlled release rates for each factor [9]. This bears the advantage that the angiogenic process is stimulated much more efficiently than by the use of one growth factor alone. In fact, studies could demonstrate that the incorporation of multiple growth factors into scaffolds resulted in a markedly improved vascularization and the development of mature pericyte-coated microvascular networks inside the implants [10, 39, 40]. Gérard et al. [41] recently reported that the proangiogenic effect of growth factors can be further improved by combining them with copper sulfate. Finally, scaffolds may also be enriched with plasmid DNA to stimulate the local cellular production of angiogenic growth factors at the implantation site $[42,43]$. 
An improved vascularization of scaffolds is also achieved by seeding them with differentiated tissue-specific cells $[11,44]$ or multipotent stem cells $[45,46]$. These cells contribute to the vascularization process via different mechanisms. On the one hand, the cells inside a construct stimulate the ingrowth of blood vessels by releasing angiogenic growth factors. In fact, after implantation into a defect, they initially lack a blood supply of their own and, thus, suffer from hypoxia. This is typically associated with the intracellular upregulation of hypoxiainducible factor (HIF)- $1 \alpha$ and HIF- $1 \alpha$-mediated expression of VEGF [47]. On the other hand, in contrast to tissue-specific cells, stem cells exhibit the capacity to differentiate into vascular cells and to self-assemble into novel microvessels [48]. Schumann et al. [11] recently seeded both cell types, i.e. osteoblast-like cells and bone marrow-derived mesenchymal stem cells, on PLGA scaffolds and analyzed their vascularization during a 14-day implantation period. Of interest, blood vessel ingrowth into the constructs was markedly improved when compared to nonseeded control scaffolds due to an increased expression of VEGF with comparable results for both seeded cell types. These findings indicate that the vascularization was mainly driven by the production of VEGF rather than by the vessel-forming capacity of the bone marrow-derived mesenchymal stem cells. Other studies could demonstrate that this vascularization strategy may be further optimized by seeding scaffolds with genetically modified cells, which continuously secrete angiogenic growth factors, independently from their state of hypoxia $[49,50]$.

Furthermore, it is possible to promote the development of new blood vessels by stimulating the homing of circulating stem cells. These cells have been shown to be recruited to ischemic sites via the stromal-cell-derived factor 1/chemokine receptor type 4 axis [51]. Accordingly, incorporation of stromal-cell-derived factor 1 into PLGA and polycaprolactone scaffolds results in an accumulation of stem cells at the implantation site, which is associated with an enhanced angiogenic host tissue response to the implants $[52,53]$. Besides, the recruitment of stem cells into tissue constructs may also be stimulated by cell seeding. For instance, Tasso et al. [54] generated porous ceramic cubes seeded with mouse mesenchymal stem cells and found after implantation into syngeneic mice that in contrast to nonseeded control scaffolds these constructs were capable of recruiting circulating endothelial progenitor cells and pericyte-like cells.

Finally, recent progress in the field of computational modeling now offers the possibility to simulate the in- growth of new blood vessels into scaffolds under highly standardized conditions [55-57]. Accordingly, this in silico approach may crucially contribute to the future optimization of scaffold architecture as well as growth factor incorporation and cell seeding of scaffolds.

\section{Inosculation in Tissue Engineering}

The pivotal problem in vascularizing implanted tissue constructs through angiogenesis is the fact that the development of new blood vessels is a time-consuming process, which can only be accelerated to a limited extent. Studies estimate that the physiological growth rate of microvessels is not faster than approximately $5 \mu \mathrm{m} / \mathrm{h}[58$, 59]. Accordingly, even highly successful proangiogenic strategies will not be able to prevent cell death in the center of large 3-dimensional tissue constructs during the initial days after implantation.

These considerations have led to the introduction of prevascularization approaches in the field of tissue engineering. The basic idea of these approaches is the generation of preformed microvascular networks within tissue constructs prior to their implantation. In this case, the networks simply have to develop interconnections to the blood vessels of the host tissue at the implantation site, which is also termed inosculation [7]. This bears the major advantage that the implants are fully blood-perfused within a short period of time, independently from their size and 3-dimensional design.

There are different possibilities for the prevascularization of tissue constructs. In vitro, scaffolds may be seeded with endothelial cells or endothelial progenitor cells, which have the capacity to self-assemble spontaneously into capillary-like structures [60, 61]. However, these structures are often unstable. To overcome this problem, the cells may be transfected with genes, which enhance their survival $[62,63]$. Because such a genetic manipulation is always associated with an oncogenic risk, a better alternative may be the coseeding of scaffolds with endothelial cells and vessel-stabilizing cell types. Koike et al. [64] incorporated human umbilical vein endothelial cells (HUVECs) and 10T1/2 mesenchymal precursor cells into fibronectin type I collagen gels, which were then implanted into mice. By this, they could demonstrate that the HUVECs formed interconnected blood-perfused vessels, which were covered with 10T1/2 cells expressing the mural-cell marker $\alpha$-smooth muscle actin. These vessels were stable and functional for 1 year. In contrast, constructs that were seeded with HUVECs 
alone only showed a minimal perfusion and already regressed after 60 days.

Prevascularized tissue constructs may also be generated in situ by implanting scaffolds into a well-vascularized implantation site of the body, which then serves as a natural bioreactor $[65,66]$. Thereby, a microvascular network develops within the implants by the ingrowth of microvessels from the surrounding host microvasculature. After establishing a sufficient vascularization, the constructs are explanted and transferred into the final defect site. This approach bears the advantage that fully functional blood vessels are formed in the implants without the need of complex cell isolation, seeding and cultivation procedures. However, it requires the implantation of scaffolds for prevascularization, their removal and the final insertion into the host defect. Thus, it should be considered that each of these surgical interventions may be associated with intra- and postoperative complications.

Once a prevascularized tissue construct has been successfully generated in vitro or in situ, it should rapidly develop interconnections to the blood vessels of the host tissue after implantation. This involves the growth of vascular sprouts originating from the host microvasculature towards the connecting ends of the implants' preformed microvessels and vice versa. Recent studies indicate that this growth is directed by specialized endothelial cells at the tips of sprouts, which extend multiple filopodia along VEGF-A gradients $[67,68]$. These cells are followed by proliferating endothelial stalk cells, resulting in the elongation of the sprouts. Finally, the inosculation of encountering sprouts is crucially dependent on the balance between Notch and Wnt signaling, which controls the stability of new vessel connections [69].

In the past, most studies suggested that inosculation takes place inside prevascularized grafts due to the regression of preformed microvessels and invasion of microvessels of host origin [70, 71] (fig. 1). However, more recent studies show that the preformed microvessels can also grow outside the implants, promoting external inosculation in the surrounding host tissue and, thus, improving vascularization of the implantation site [65] (fig. 1). In addition, the sprouting angiogenic activity of the preformed microvessels also contributes to an increased microvessel density in the center of the implants [65]. These findings indicate that preformed microvascular networks are highly dynamic and actively contribute to the establishment of a sufficient blood supply to tissue constructs after implantation.

Vascularization in Tissue Engineering

\section{Promoting Inosculation of Prevascularized Tissue Constructs}

Although the inosculation of preformed microvessels represents a promising vascularization strategy in tissue engineering, experimental studies show that even this approach cannot guarantee an adequate blood perfusion of tissue constructs during the very first days after implantation $[60,65]$. This is not surprising, because inosculation is also dependent on angiogenic processes, such as the angiogenic activation of the preformed microvessels and the host microvasculature and their growth towards each other. Thus, there is a reasonable need for the establishment of novel strategies, which further optimize the inosculation of prevascularized tissue constructs.

We recently analyzed the effect of cultivation of in situ prevascularized tissue constructs prior to their implantation [72]. Of interest, we found that short-term cultivation for 3 days in Dulbecco's modified Eagle's medium reduced the number of $\alpha$-smooth-muscle-actin-positive preformed microvessels and increased the cellular production of VEGF within the constructs. After implantation, this resulted in an accelerated inosculation of the preformed microvessels when compared to those of noncultivated control implants. In another study, we additionally embedded the prevascularized tissue constructs in Matrigel during the cultivation period [73]. By this, we could stimulate the outgrowth of preformed microvessels into the proangiogenic extracellular matrix, which promoted external inosculation of the constructs with the host microvasculature and markedly improved the implants' vascularization during the first 14 days after implantation.

Taken together, these findings demonstrate that inosculation can be optimized by modification of the angiogenic activity of preformed microvascular networks within tissue constructs. On the other hand, it may also be possible to improve the angiogenic host tissue response and, thus, to accelerate the directed growth of microvessels from the host microvasculature towards the implants. Nonetheless, despite these approaches the natural inosculation of two microvascular networks will always be a process that takes hours to days [72, 73]. Accordingly, inosculation strategies may be combined in the future with preconditioning methods, which increase the ischemic tolerance of cells inside tissue constructs during the initial phase after implantation [74]. Alternatively, prevascularized tissue constructs comprising a vascular pedicle may be generated by flap fabrication [75] or by using an arteriovenous loop [76]. This approach bears the 
major advantage that the blood vessels of the constructs can be directly anastomosed to the host microvasculature by means of microsurgical techniques during the implantation procedure, resulting in an immediate restoration of blood perfusion within the implants.

\section{Conclusions and Future Perspectives}

By now, there is no doubt that the major precondition for the successful transfer of tissue engineering applications into clinical practice is the establishment of effective strategies, which guarantee an adequate blood supply to implanted tissue constructs. Accordingly, sophisticated approaches have been developed, which improve the ingrowth of new blood vessels into tissue constructs. However, because angiogenesis is a time-consuming process, these approaches alone cannot prevent ischemic cell death within larger 3-dimensional tissue substitutes during the initial days after implantation. The generation of preformed microvascular networks within the implants and their subsequent inosculation at the implantation site represent a promising alternative to overcome this problem. Nonetheless, recent studies indicate that there is still a need to optimize such prevascularization strategies. Novel insights into the regulatory mechanisms of angiogenesis and network formation as well as further progress in the fields of computational modeling, biomaterial research and microsurgery will contribute to achieve this goal in the near future.

\section{References}

1 Langer R, Vacanti JP: Tissue engineering. Science 1993;260:920-926.

2 Tsang VL, Bhatia SN: Fabrication of threedimensional tissues. Adv Biochem Eng Biotechnol 2007;103:189-205.

3 Chen W, Tabata Y, Tong YW: Fabricating tissue engineering scaffolds for simultaneous cell growth and drug delivery. Curr Pharm Des 2010;16:2388-2394.

4 Santos MI, Reis RL: Vascularization in bone tissue engineering: physiology, current strategies, major hurdles and future challenges. Macromol Biosci 2010;10:12-27.

5 Novosel EC, Kleinhans C, Kluger PJ: Vascularization is the key challenge in tissue engineering. Adv Drug Deliv Rev 2011;63:300311.

6 Laschke MW, Harder Y, Amon M, Martin I, Farhadi J, Ring A, Torio-Padron N, Schramm R, Rücker M, Junker D, Häufel JM, Carvalho C, Heberer M, Germann G, Vollmar B, Menger MD: Angiogenesis in tissue engineering: breathing life into constructed tissue substitutes. Tissue Eng 2006;12:20932104.

7 Laschke MW, Vollmar B, Menger MD: Inosculation: connecting the life-sustaining pipelines. Tissue Eng Part B Rev 2009;15: 455-465.

8 Carmeliet P, Jain RK: Molecular mechanisms and clinical applications of angiogenesis. Nature 2011;473:298-307.

-9 Richardson TP, Murphy WL, Mooney DJ: Polymeric delivery of proteins and plasmid DNA for tissue engineering and gene therapy. Crit Rev Eukaryot Gene Expr 2001;11: $47-58$.
10 Laschke MW, Rücker M, Jensen G, Carvalho C, Mülhaupt R, Gellrich NC, Menger MD: Incorporation of growth factor containing Matrigel promotes vascularization of porous PLGA scaffolds. J Biomed Mater Res A 2008; 85:397-407.

11 Schumann P, Tavassol F, Lindhorst D, Stuehmer C, Bormann KH, Kampmann A, Mülhaupt R, Laschke MW, Menger MD, Gellrich NC, Rücker M: Consequences of seeded cell type on vascularization of tissue engineering constructs in vivo. Microvasc Res 2009;78:180-190.

12 Carmeliet P: Mechanisms of angiogenesis and arteriogenesis. Nat Med 2000;6:389395.

13 Rücker M, Laschke MW, Junker D, Carvalho C, Schramm A, Mülhaupt R, Gellrich NC, Menger MD: Angiogenic and inflammatory response to biodegradable scaffolds in dorsal skinfold chambers of mice. Biomaterials 2006;27:5027-5038.

14 Anderson CR, Ponce AM, Price RJ: Immunohistochemical identification of an extracellular matrix scaffold that microguides capillary sprouting in vivo. J Histochem $\mathrm{Cy}$ tochem 2004;52:1063-1072.

15 Butler MJ, Sefton MV: Poly(butyl methacrylate-co-methacrylic acid) tissue engineering scaffold with pro-angiogenic potential in vivo. J Biomed Mater Res A 2007;82:265273.

16 Rücker M, Laschke MW, Junker D, Carvalho C, Tavassol F, Mülhaupt R, Gellrich NC, Menger MD: Vascularization and biocompatibility of scaffolds consisting of different calcium phosphate compounds. J Biomed Mater Res A 2008;86:1002-1011.
17 Laschke MW, Strohe A, Scheuer C, Eglin D, Verrier S, Alini M, Pohlemann T, Menger $\mathrm{MD}$ : In vivo biocompatibility and vascularization of biodegradable porous polyurethane scaffolds for tissue engineering. Acta Biomater 2009;5:1991-2001.

18 Laschke MW, Strohe A, Menger MD, Alini $\mathrm{M}$, Eglin D: In vitro and in vivo evaluation of a novel nanosize hydroxyapatite particles/ poly(ester-urethane) composite scaffold for bone tissue engineering. Acta Biomater 2010;6:2020-2027.

19 Druecke D, Langer S, Lamme E, Pieper J, Ugarkovic M, Steinau HU, Homann HH: Neovascularization of poly(ether ester) block-copolymer scaffolds in vivo: longterm investigations using intravital fluorescent microscopy. J Biomed Mater Res A 2004; 68:10-18.

20 Galperin A, Long TJ, Ratner BD: Degradable, thermo-sensitive poly( $\mathrm{N}$-isopropyl acrylamide)-based scaffolds with controlled porosity for tissue engineering applications. Biomacromolecules 2010;11:2583-2592.

21 Madden LR, Mortisen DJ, Sussman EM, Dupras SK, Fugate JA, Cuy JL, Hauch KD, Laflamme MA, Murry CE, Ratner BD: Proangiogenic scaffolds as functional templates for cardiac tissue engineering. Proc Natl Acad Sci USA 2010;107:15211-15216.

22 Yang H, Yang S, Chi X, Evans JR: Fine ceramic lattices prepared by extrusion freeforming. J Biomed Mater Res B Appl Biomater 2006;79:116-121.

23 Borenstein JT, Weinberg EJ, Orrick BK, Sundback C, Kaazempur-Mofrad MR, Vacanti JP: Microfabrication of three-dimensional engineered scaffolds. Tissue Eng 2007;13:18371844. 
-24 Kaigler D, Wang Z, Horger K, Mooney DJ, Krebsbach PH: VEGF scaffolds enhance angiogenesis and bone regeneration in irradiated osseous defects. J Bone Miner Res 2006; 21:735-744.

$25 \mathrm{He}$ Q, Zhao Y, Chen B, Xiao Z, Zhang J, Chen L, Chen W, Deng F, Dai J: Improved cellularization and angiogenesis using collagen scaffolds chemically conjugated with vascular endothelial growth factor. Acta Biomater 2011;7:1084-1093.

26 Guan J, Stankus JJ, Wagner WR: Biodegradable elastomeric scaffolds with basic fibroblast growth factor release. J Control Release 2007;120:70-78.

-27 Zhao W, Han Q, Lin H, Sun W, Gao Y, Zhao Y, Wang B, Wang X, Chen B, Xiao Z, Dai J: Human basic fibroblast growth factor fused with Kringle4 peptide binds to a fibrin scaffold and enhances angiogenesis. Tissue Eng Part A 2009;15:991-998.

-28 Li B, Davidson JM, Guelcher SA: The effect of the local delivery of platelet-derived growth factor from reactive two-component polyurethane scaffolds on the healing in rat skin excisional wounds. Biomaterials 2009; 30:3486-3494.

29 Shi H, Han C, Mao Z, Ma L, Gao C: Enhanced angiogenesis in porous collagen-chitosan scaffolds loaded with angiogenin. Tissue Eng Part A 2008;14:1775-1785.

30 Chiu LL, Radisic M: Scaffolds with covalently immobilized VEGF and angiopoietin-1 for vascularization of engineered tissues. Biomaterials 2010;31:226-241.

-31 Miyagi Y, Chiu LL, Cimini M, Weisel RD, Radisic M, Li RK: Biodegradable collagen patch with covalently immobilized VEGF for myocardial repair. Biomaterials 2011;32 $1280-1290$

- 32 Lindhorst D, Tavassol F, von See C, Schumann P, Laschke MW, Harder Y, Bormann $\mathrm{KH}$, Essig H, Kokemüller H, Kampmann A, Voss A, Mülhaupt R, Menger MD, Gellrich NC, Rücker M: Effects of VEGF loading on scaffold-confined vascularization. J Biomed Mater Res A 2010;95:783-792.

- 33 Anderson SM, Siegman SN, Segura T: The effect of vascular endothelial growth factor (VEGF) presentation within fibrin matrices on endothelial cell branching. Biomaterials 2011;32:7432-7443.

- 34 Perets A, Baruch Y, Weisbuch F, Shoshany G, Neufeld G, Cohen S: Enhancing the vascularization of three-dimensional porous alginate scaffolds by incorporating controlled release basic fibroblast growth factor microspheres. J Biomed Mater Res A 2003;65:489497.

35 Ennett AB, Kaigler D, Mooney DJ: Temporally regulated delivery of VEGF in vitro and in vivo. J Biomed Mater Res A 2006;79:176184.
Hiraoka Y, Yamashiro H, Yasuda K, Kimura $\mathrm{Y}$, Inamoto $\mathrm{T}$, Tabata $\mathrm{Y}$ : In situ regeneration of adipose tissue in rat fat pad by combining a collagen scaffold with gelatin microspheres containing basic fibroblast growth factor. Tissue Eng 2006;12:1475-1487.

- 37 Rocha FG, Sundback CA, Krebs NJ, Leach JK, Mooney DJ, Ashley SW, Vacanti JP, Whang EE: The effect of sustained delivery of vascular endothelial growth factor on angiogenesis in tissue-engineered intestine. Biomaterials 2008;29:2884-2890.

38 Borselli C, Ungaro F, Oliviero O, d'Angelo I, Quaglia F, La Rotonda MI, Netti PA: Bioactivation of collagen matrices through sustained VEGF release from PLGA microspheres. J Biomed Mater Res A 2010;92:94102.

-39 Nillesen ST, Geutjes PJ, Wismans R, Schalkwijk J, Daamen WF, van Kuppevelt TH: Increased angiogenesis and blood vessel maturation in acellular collagen-heparin scaf folds containing both FGF2 and VEGF. Biomaterials 2007;28:1123-1131.

40 Sun G, Shen YI, Kusuma S, Fox-Talbot K, Steenbergen CJ, Gerecht S: Functional neovascularization of biodegradable dextran hydrogels with multiple angiogenic growth factors. Biomaterials 2011;32:95-106.

41 Gérard C, Bordeleau LJ, Barralet J, Doillon CJ: The stimulation of angiogenesis and collagen deposition by copper. Biomaterials 2010;31:824-831.

42 Mao Z, Shi H, Guo R, Ma L, Gao C, Han C, Shen J: Enhanced angiogenesis of porous collagen scaffolds by incorporation of TMC/ DNA complexes encoding vascular endothelial growth factor. Acta Biomater 2009;5: 2983-2994

43 Guo R, Xu S, Ma L, Huang A, Gao C: The healing of full-thickness burns treated by using plasmid DNA encoding VEGF-165 activated collagen-chitosan dermal equivalents. Biomaterials 2011;32:1019-1031.

44 Tavassol F, Schumann P, Lindhorst D, Sinikovic B, Voss A, von See C, Kampmann A, Bormann KH, Carvalho C, Mülhaupt R, Harder Y, Laschke MW, Menger MD, Gellrich NC, Rücker M: Accelerated angiogenic host tissue response to poly(L-lactide-co-glycolide) scaffolds by vitalization with osteoblast-like cells. Tissue Eng Part A 2010;16: 2265-2279.

45 Moioli EK, Clark PA, Chen M, Dennis JE, Erickson HP, Gerson SL, Mao JJ: Synergistic actions of hematopoietic and mesenchymal stem/progenitor cells in vascularizing bioengineered tissues. PLoS One 2008;3:e3922.

46 Liu S, Zhang H, Zhang X, Lu W, Huang X, Xie H, Zhou J, Wang W, Zhang Y, Liu Y, Deng $Z$, Jin Y: Synergistic angiogenesis promoting effects of extracellular matrix scaffolds and adipose-derived stem cells during wound repair. Tissue Eng Part A 2011;17:725-739.

$\checkmark 47$ Benizri E, Ginouvès A, Berra E: The magic of the hypoxia-signaling cascade. Cell Mol Life Sci 2008;65:1133-1149.
48 Singh S, Wu BM, Dunn JC: Accelerating vascularization in polycaprolactone scaffolds by endothelial progenitor cells. Tissue Eng Part A 2011;17:1819-1830.

-49 Lasso JM, Del Río M, García M, Martínez Calleja V, Nava P, Muñoz-Fernández MA, Pérez Cano R: Improving flap survival by transplantation of a VEGF-secreting endothelised scaffold during distal pedicle flap creation. J Plast Reconstr Aesthet Surg 2007; 60:279-286.

-50 Qu D, Li J, Li Y, Gao Y, Zuo Y, Hsu Y, Hu J: Angiogenesis and osteogenesis enhanced by bFGF ex vivo gene therapy for bone tissue engineering in reconstruction of calvarial defects. J Biomed Mater Res A 2011;96A:543551.

51 Ceradini DJ, Gurtner GC: Homing to hypoxia: HIF-1 as a mediator of progenitor cell recruitment to injured tissue. Trends Cardiovasc Med 2005;15:57-63.

52 Schantz JT, Chim H, Whiteman M: Cell guidance in tissue engineering: SDF-1 mediates site-directed homing of mesenchymal stem cells within three-dimensional polycaprolactone scaffolds. Tissue Eng 2007;13: 2615-2624.

53 Thevenot PT, Nair AM, Shen J, Lotfi P, Ko CY, Tang L: The effect of incorporation of SDF-1alpha into PLGA scaffolds on stem cell recruitment and the inflammatory response. Biomaterials 2010;31:3997-4008.

-54 Tasso R, Fais F, Reverberi D, Tortelli F, Cancedda R: The recruitment of two consecutive and different waves of host stem/progenitor cells during the development of tissue-engineered bone in a murine model. Biomaterials 2010;31:2121-2129.

- 55 Lemon G, Howard D, Tomlinson MJ, Buttery LD, Rose FR, Waters SL, King JR: Mathematical modelling of tissue-engineered angiogenesis. Math Biosci 2009;221:101-120.

-56 Artel A, Mehdizadeh H, Chiu YC, Brey EM, Cinar A: An agent-based model for the investigation of neovascularization within porous scaffolds. Tissue Eng Part A 2011;17:21332141.

57 Lemon G, Howard D, Rose FR, King JR: Individual-based modelling of angiogenesis inside three-dimensional porous biomaterials. Biosystems 2011;103:372-383.

58 Zarem HA: The microcirculatory events within full-thickness skin allografts (homografts) in mice. Surgery 1969;66:392-397.

59 Orr AW, Elzie CA, Kucik DF, Murphy-Ullrich JE: Thrombospondin signaling through the calreticulin/LDL receptor-related protein co-complex stimulates random and directed cell migration. J Cell Sci 2003;116: 2917-2927.

-60 Tremblay PL, Hudon V, Berthod F, Germain L, Auger FA: Inosculation of tissue-engineered capillaries with the host's vasculature in a reconstructed skin transplanted on mice. Am J Transplant 2005;5:1002-1010. 
-61 Shepherd BR, Enis DR, Wang F, Suarez Y, Pober JS, Schechner JS: Vascularization and engraftment of a human skin substitute using circulating progenitor cell-derived endothelial cells. FASEB J 2006;20:1739-1741.

62 Schechner JS, Nath AK, Zheng L, Kluger MS, Hughes CC, Sierra-Honigmann MR, Lorber MI, Tellides G, Kashgarian M, Bothwell AL, Pober JS: In vivo formation of complex microvessels lined by human endothelial cells in an immunodeficient mouse. Proc Natl Acad Sci USA 2000;97:9191-9196.

63 Yang J, Nagavarapu U, Relloma K, Sjaastad MD, Moss WC, Passaniti A, Herron GS: Telomerized human microvasculature is functional in vivo. Nat Biotechnol 2001;19: 219-224.

64 Koike N, Fukumura D, Gralla O, Au P, Schechner JS, Jain RK: Tissue engineering: creation of long-lasting blood vessels. Nature 2004;428:138-139.

-65 Laschke MW, Rücker M, Jensen G, Carvalho C, Mülhaupt R, Gellrich NC, Menger MD: Improvement of vascularization of PLGA scaffolds by inosculation of in situ-preformed functional blood vessels with the host microvasculature. Ann Surg 2008;248: 939-948.
66 Kokemueller H, Spalthoff S, Nolff M, Tavassol F, Essig H, Stuehmer C, Bormann KH, Rücker M, Gellrich NC: Prefabrication of vascularized bioartificial bone grafts in vivo for segmental mandibular reconstruction: experimental pilot study in sheep and first clinical application. Int J Oral Maxillofac Surg 2010;39:379-387.

67 Gerhardt H, Golding M, Fruttiger M, Ruhrberg C, Lundkvist A, Abramsson A, Jeltsch M, Mitchell C, Alitalo K, Shima D, Betsholtz C: VEGF guides angiogenic sprouting utilizing endothelial tip cell filopodia. J Cell Biol 2003;161:1163-1177.

68 Gerhardt H, Betsholtz C: How do endothelial cells orientate? EXS 2005;94:3-15.

69 Phng LK, Potente M, Leslie JD, Babbage J, Nyqvist D, Lobov I, Ondr JK, Rao S, Lang RA, Thurston G, Gerhardt H: Nrarp coordinates endothelial Notch and Wnt signaling to control vessel density in angiogenesis. Dev Cell 2009;16:70-82.

70 Demarchez M, Hartmann DJ, Prunieras M: An immunohistological study of the revascularization process in human skin transplanted onto the nude mouse. Transplantation 1987;43:896-903.

71 Capla JM, Ceradini DJ, Tepper OM, Callaghan MJ, Bhatt KA, Galiano RD, Levine JP, Gurtner GC: Skin graft vascularization involves precisely regulated regression and replacement of endothelial cells through both angiogenesis and vasculogenesis. Plast Reconstr Surg 2006;117:836-844.
72 Laschke MW, Mussawy H, Schuler S, Kazakov A, Rücker M, Eglin D, Alini M, Menger MD: Short-term cultivation of in situ prevascularized tissue constructs accelerates inosculation of their preformed microvascular networks after implantation into the host tissue. Tissue Eng Part A 2011;17:841-853.

73 Laschke MW, Mussawy H, Schuler S, Eglin $\mathrm{D}$, Alini M, Menger MD: Promoting external inosculation of prevascularised tissue constructs by pre-cultivation in an angiogenic extracellular matrix. Eur Cell Mater 2010;20: 356-366.

74 Tavassol F, Kampmann A, Lindhorst D, Schumann P, Kokemüller H, Bormann KH, Gellrich NC, Rücker M: Prolongated survival of osteoblast-like cells on biodegradable scaffolds by heat shock preconditioning. Tissue Eng Part A 2011;17:1935-1943.

75 Warnke PH, Wiltfang J, Springer I, Acil Y, Bolte H, Kosmahl M, Russo PA, Sherry E, Lützen U, Wolfart S, Terheyden H: Man as living bioreactor: fate of an exogenously prepared customized tissue-engineered mandible. Biomaterials 2006;27:3163-3167.

76 Ren LL, Ma DY, Feng X, Mao TQ, Liu YP, Ding Y: A novel strategy for prefabrication of large and axially vascularized tissue engineered bone by using an arteriovenous loop. Med Hypotheses 2008;71:737-740. 